\title{
3 \\ The Higher Education Contribution Scheme: Keeping tertiary education affordable and accessible
}

\author{
Timothy Higgins ${ }^{1}$
}

\section{A policy success?}

The Higher Education Contribution Scheme (HECS) ${ }^{2}$ was a key part of the 1988 Dawkins reforms to the Australian higher education landscape. ${ }^{3}$ In 1987, there was an urgent economic case for expansion of the higher education sector, which led then education minister John Dawkins to embark on a path of ambitious and radical policy reform. The organisational process was efficient and rapid and the capable individuals assisting Dawkins were deliberately chosen, setting out persuasive arguments

1 I would like to acknowledge and thank Bruce Chapman and Meredith Edwards for their helpful comments on an earlier version of this chapter, and John Dawkins for directing me to a number of useful resources as I researched the early history of HECS.

2 HECS was renamed HECS-HELP after being incorporated into the umbrella Higher Education Loan Program (HELP) introduced in the 2003-04 Budget. We refer to HECS and HECS-HELP interchangeably in this chapter.

3 The focus of this chapter is on HECS, rather than the broader Dawkins higher education reforms, of which HECS was just one, albeit central, part. For a detailed insider's account of the development of HECS, see Edwards et al. (2001). For comprehensive accounts of the history, development and assessment of the consequences of the Dawkins reforms more broadly, see Macintyre et al. (2017) and Croucher et al. (2013). 
for student contributions and carefully designed policy features and parameters that were critical to the acceptance of HECS. HECS has successfully facilitated the growth in higher education participation and graduate outcomes that motivated its development. The policy has broad public and political support and endures 30 years after implementation. It is also a policy export success, with many countries adopting incomecontingent loan (ICL) schemes following Australia's pioneering lead. Its endurance, broad public and political acceptance and international adoption are testament to the operational efficiency and economic and social fairness of HECS.

A summary of why HECS is considered a policy success follows. The remaining sections of this chapter set out in greater detail the context, motivation, people involved, development and delivery processes, policy changes since implementation and the challenges and risks HECS faces today.

\section{Programmatic assessment}

The political and economic environment of the 1980s set the scene for the development of HECS. As the 1980s progressed, it was clear that, for the sake of productivity and prosperity, a larger skilled workforce was needed, and there was increasing unmet demand by school completers for university places. Fiscal pressures meant it was neither politically nor economically attractive for government to fund expansion of the higher education sector predominantly through public funds.

It was also apparent that those attending university were predominantly from the middle and upper classes and, moreover, the private benefits for those with university degrees were substantial. It was therefore unfair that taxpayers should be footing the bill for privileged students to attend university. This amounted to 'middle-class welfare'. These arguments were used to justify the public value proposition that students should contribute to the costs of their education.

Abolition of fees under the Whitlam Government in 1974 was considered to be a central element of Australian Labor Party (ALP) ideology, with so-called free education on the ALP platform; thus, the reintroduction of fees appeared politically implausible. Nor, it was argued, did fee reintroduction make sense on equity grounds, since upfront fees would harm access for poorer students. The challenge facing Dawkins and 
the Labor Government in 1987 was to finance expansion of the higher education sector through contributions from the students who directly benefited, but in a way that did not involve reintroduction of upfront tuition fees.

The attraction of HECS was that it provided students with a deferred loan to cover tuition fees, ensuring that those without upfront funds could still participate. Unlike conventional loans, HECS was an ICL, such that repayments would be a proportion of income, repaid only if and when income exceeded average earnings, thereby reducing to zero a debtor's risk of default and minimising financial hardship. Thus, only relatively well-off debtors would repay, and the scheme was 'fair' because repayments would be made only by those with above-average earnings.

The evidence is compelling that HECS achieved its intended social outcomes by successfully facilitating expansion of the higher education system and graduate population without compromising access. Although the introduction of HECS meant that students were faced with feesalbeit deferred - the revenue HECS provided to universities created places for many who were previously turned away. Following implementation, much of the unmet demand by school completers was met and growth in the number of domestic students outpaced population growth, increasing from 2.3 per cent of the estimated resident population in 1985 to 3.3 per cent by 1995 (James et al. 2013). By 2016, the higher education sector's domestic student load (in equivalent full-time student load) had reached 740,223-more than double the 1987 level-and more than 2.5 million individuals have now benefited from the scheme (Ey 2018). The increased participation rates have translated into a more educated and employable workforce, with the proportion of the working-age population with a degree rising from 8 per cent in 1988 to 31 per cent in 2018 (ABS 2017).

Research undertaken soon after its implementation found HECS had little effect on deterring enrolments. While absolute increases in participation numbers were higher among more advantaged students, there was little change in the proportions of applicants from different socioeconomic groups: 'The tide of expanded participation lifted all boats' (James et al. 2013: 141). Changes to HECS parameters over the intervening years have pushed a greater share of costs on to students, but despite these and other changes, research has shown that, on balance, neither the introduction 
of HECS nor subsequent policy change has significantly affected participation or the socioeconomic mix of students attending university (Chapman and Nicholls 2013; James et al. 2013).

As intended, HECS shifted the costs of higher education from the public to the students who benefited directly. Following the introduction of HECS, the public share of expenditure on higher education declined sharply while the private share increased. In 1987, Commonwealth funding made up more than 80 per cent of university income, whereas in 2017 it covered close to 40 per cent of spending on universities (excluding outlays and subsidies from unpaid Higher Education Loans Program, or HELP, loans) (Norton et al. 2018). That the majority of Australian tertiary education expenditure is derived from private sources contrasts with the Organisation for Economic Co-operation and Development (OECD) average split of 70 per cent public and 30 per cent private (OECD 2017). Nevertheless, overall funding remains internationally competitive; total investment in tertiary education in Australia in 2014 was 1.8 per cent of gross domestic product (GDP), exceeding the OECD average of 1.6 per cent (OECD 2017: Table B2.3). It can be argued that, by reducing government spending while ensuring a healthy higher education sector, HECS has succeeded in facilitating the affordable expansion of the sector.

However, quantifying the private and public returns to higher education is problematic, and what constitutes affordability is subjective. The debate about the 'correct' level of student charges versus public funding continues, yet the arguments put forward in 1988 for student contributions still hold today; graduates continue to receive very high private benefits from university (Daly et al. 2015) and the socioeconomic mix of participants is still weighted towards the middle and upper classes.

\section{Process assessment}

The policy process moved quickly following the appointment in July 1987 of Dawkins as minister for the Department of Employment, Education and Training (DEET), with HECS becoming law only 18 months later, on 1 January 1989. Key to the success were the drive and focus of Dawkins and the rigour involved in the policy design and decision-making process. Dawkins selected skilled advisors to review the higher education sector and gather information that supported the case for change. The team included ANU economist Bruce Chapman, whom Dawkins tasked with setting out options for student contributions. Despite the speed of delivery, the 
policy idea of HECS was not conceived or proposed from the outset. There was no published research paper setting out the idea to which the government could refer. Instead, the Wran committee, established by Dawkins to review the different funding options set out by Chapman, objectively assessed options before settling on HECS, which seemed to meet the needs for expansion via user pays while not harming access. Edwards et al. (2001: 134) remark on the importance of the intellectual depth and substance' of the analytical stage of the policy design process.

Edwards also recalls that, while the consultation process was brief, it was particularly well focused (personal correspondence). The objectivity and rigour of the analysis of the problems with existing funding arrangements and options for reform, and the clear articulation of the economic arguments, helped Dawkins and his supporters deliver the policy.

\section{Political assessment}

The endurance of HECS is a testament to its success, as both major political parties view it as an essential component of the Australian higher education system. HECS is regarded by the media and policy commentators as a key example of Australia's policy export success stories. Following Australia's demonstration of the feasibility of an ICL for higher education tuition, ICL schemes were adopted in eight other countries, including New Zealand (in 1992), the United Kingdom (1997), Ethiopia (2001), Hungary (2003) and South Korea (2011), with other countries currently seriously investigating implementation, including Colombia, Brazil and Malaysia (Chapman 2018).

Public, industry and academic acceptance and acknowledgement of the success of HECS are also apparent through the accolades lauded on Chapman-widely regarded as the 'architect' of HECS. Most recently, this has included the Australian Financial Review's Higher Education Lifetime Achievement Award (Dodd 2017), for which the judges noted that, because of HECS, 'Australia has been able to expand access to higher education in an equitable and cost-effective way'. The Australian HECS system has also been lauded in the international media (see, for example, Chingos and Dynarksi 2018).

While the success of HECS has led to domestic expansion into other education sectors, this has also revealed limitations and risks. Expansion into the vocational education sector through the introduction of vocational 
education and training (VET) FEE-HELP in 2008 exposed an imbalance in the risk-sharing arrangements between educational institutions and government. The current arrangement of capped and uniform HECS charges has also limited incentives for the higher education sector to innovate and diversify. HECS has been resilient and endured for the past 30 years, but the rising stock and cost of debt and calls to reform the higher education sector pose challenges. The pressures and challenges facing HECS are discussed in the final section of this chapter.

\section{Setting the scene}

Before 1973, students paid tuition fees to attend university in Australia, although the majority of students were on scholarships and fees covered only 15 per cent of the costs of tuition. The full abolition of fees in 1973 by the Whitlam Government became a key feature of the ALP's platform and ideology. Unsurprisingly, this was particularly popular among students and, as demand and enrolments increased throughout the 1970s, public funding for the university sector became strained. Subsequent attempts to reintroduce fees for first degrees under the Fraser Government failed, due in part to strong student protests. The Fraser Government introduced fees for second and higher degree students (Edwards et al. 2001), but pressure on education funding continued to grow. Despite recognition of the need to expand the supply of higher education places to increase skills and reduce youth unemployment, public funding as a proportion of GDP fell from 1.36 per cent in 1975 to 1.08 per cent by 1982 (Dawkins 1987a).

In 1983, the new Hawke Labor Government came to power, inheriting a dire budgetary position (Dawkins 2018). A slowing economy and global recession in the early 1980s had put considerable pressure on government, and Labor responded by embarking on significant policy reforms, including financial deregulation to improve competition and economic efficiency. A surging trade deficit led to a decline in the Australian dollar and expansion of the financial sector drove up inflation. Deteriorating conditions in the economy led to treasurer Paul Keating's provocative warning in 1986 that Australia risked becoming 'a banana republic'. In 1987, Labor announced plans for microeconomic reform, but it was clear that fiscal constraints meant the university sector could not expect an increase in public spending (Macintyre et al. 2017). By 1987, the 
university sector was reliant for 85 per cent of its revenue on the federal government, while public funding had dropped to 1 per cent of GDP (Dawkins 1987a).

Despite the moves towards deregulation and market-based competition in other parts of the economy, Labor's ideology of 'free' education and fears that fees would limit equality of access inhibited plans to open up domestic higher education enrolments to market forces (Norton 2013). While the domestic market remained constrained, in 1986, the government opened the higher education sector to full-fee-paying international students, removing caps on numbers and allowing universities to retain the majority of tuition fees (Macintyre et al. 2017). However, in contrast with the present situation, where full-fee international students make up over 17 per cent of university revenue (Universities Australia 2015), in 1987, international student enrolments numbered only approximately 1,000 — providing very little towards university revenue.

Rising unmet demand for domestic university places from qualified year 12 students made clear the deficiencies in the system. This demand was brought on to a large extent by changing skill requirements during the 1980s, as low-skilled jobs declined, leading to high levels of youth unemployment and a push for greater school retention rates. The percentage of students staying on to year 12 rose from 36 per cent in 1982 to 53 per in 1987, and it was estimated that more than 10,000 qualified school-leavers were unable to secure a university place (Macintyre et al. 2017). The excess demand in turn pushed up the tertiary entrance scores needed to secure a university offer (James et al. 2013). It was also clear from demographic trends that the projected population of 17-22-year-olds was rapidly increasing and would continue to do so for some years (Dawkins 1987a).

The case for expansion and improved performance of the higher education sector was argued by government agencies and independent organisations, including the Committee for Economic Development of Australia, which released a report in 1985 on education for development, and the Economic Planning Advisory Council, which produced a 1986 paper on human capital and productivity growth (Macintyre et al. 2017). Encouragement for change also came from abroad. In the late 1980s, the OECD released reports on the Australian economy calling for the education system to address skill needs and comparatively low participation rates. 
An attempt to address the funding needs for expansion by partly shifting costs to students was taken up by finance minister Peter Walsh in his proposal of an annual fee of $\$ 1,500$ in 1985. A smaller amount, of $\$ 250$ per year, known as the Higher Education Administration Charge (HEAC), was instead introduced by the government in 1986 (Chapman and Nicholls 2013), but this covered only a small proportion of the costs of higher education. Furthermore, its introduction led to vocal student protests and there were concerns within the ALP that this fee could deter attendance by students with low financial means (Edwards et al. 2001). Nevertheless, HEAC was the first chink in the armour of free tuition that had been ALP ideology since Whitlam and provided impetus for the reforms to come.

\section{Defining the challenges}

In 1986, when HEAC was introduced, Dawkins was the Minister for Trade and the Minister Assisting the Prime Minister on Youth Affairs in the second Hawke Government, where he gained some knowledge of issues facing students. Dawkins was shadow education minister from 1980 to the start of 1983 , and his experience in the education portfolio also gave him awareness of its importance to the economy and the need for reform. In July 1987, he became minister of the newly created DEET, which merged the Department of Employment with the Department of Education and Training. The ability to manage these portfolios holistically was timely and important given the skills shortages in the labour market and the need for the education system to address these shortages.

Dawkins quickly set about driving policy change. Within a week of taking charge of DEET, he initiated a review of higher education administration. There were no terms of reference and no calls for submissions. By mid-October, he announced that the Commonwealth Tertiary Education Commission - the independent body that administered Commonwealth grants - would be abolished and replaced with a new body, the National Board of Employment, Education and Training, with more restricted functions, which would advise the minister and whose staff would be appointed by DEET (Macintyre et al. 2017). By moving administration into DEET, Dawkins gained control of the higher education financing and policy processes with less risk of interference as the government embarked on reform. 
Dawkins set out the challenges and rationale for reform in September 1987 in a paper titled The Challenge for Higher Education in Australia (Dawkins 1987b). The paper provided an overview of the shortcomings in the higher education system and made clear that the expansion should not be funded exclusively by taxpayers. But, unlike Walsh in 1985, Dawkins did not put forward tuition fees as an option, instead remarking that private sources should be considered.

The challenges were reiterated in a green paper released in December 1987 (Dawkins 1987a). As noted by Edwards et al. (2001), although this was a policy discussion paper, the style of the green paper was decisive, clearly outlining the government's ambitions for major reform. The first part of the paper proposed an indicative goal of 125,000 graduates by 2001, compared with 88,000 in 1986, with this number chosen with reference to Australia's relatively poor participation rate and graduate outputs compared with other OECD countries. To achieve this expansion, higher education enrolments would need to increase by up to 200,000 , or over 40 per cent, by 2001 .

The second part set out plans to achieve the needed reforms and establish a unified national higher education system. Changes would include closure of the binary system that had separated universities from Colleges of Advanced Education. This, and minimum student load requirements, would facilitate consolidation, resulting in fewer and larger institutions and administrative efficiencies. Other changes included course rationalisation and changes to Commonwealth and state responsibilities, institutional management processes and staffing arrangements.

The third part of the paper was titled 'Funding the System', but was intentionally kept brief, with Dawkins instead choosing to cover funding options in a separate report. Nevertheless, the green paper estimated that funding would need to increase by 30 to 40 per cent over existing Commonwealth levels to meet the needs for expansion. It was made clear that public funding for this increase was unlikely and, moreover, traditional sources of non-Commonwealth revenue (such as endowments, benefits and donations and commercial activities) would not be sufficient. Funding expansion of the sector from the public purse by raising taxes or debt was not seen as a viable option. Increases in student load had already put pressure on the funding levels per student. The macroeconomic and fiscal pressures in the broader economy were substantial and, moreover, as noted by Chapman and Hicks (2018), the Hawke Government would 
have had a strong incentive to develop an image of competent economic management to distinguish itself from the previous Labor Government of $1972-75$.

While the green paper did not spell out the proposal for what later became HECS, it indicated that students, former students and/or their parents may need to be called on to contribute. The paper concluded by announcing that a committee would be established to 'consider sources of funding involving the direct beneficiaries of higher education' (Dawkins 1987a: 87), with recommendations to be reported in early 1988 .

\section{Agents of change}

The daunting challenge was to develop policy so that students would pay a fair share for their education, but in a way that would not harm access for those with limited financial means. The political barriers appeared intractable given the ALP platform of no fees, but, as noted by those at the coalface of the development of HECS (Edwards et al. 2001; Chapman 2018), Dawkins had the right mix of determination, energy, political savvy and stubbornness.

Critical to the acceptance of HECS were the people appointed to formulate the arguments and assist in the development of the reforms. Edwards et al. (2001: 103) recollects that Dawkins deliberately chose staff for the taskforce for the green paper from the employment and training division of DEET 'who appreciated the needs of the labour market and whose thinking was unlikely to be restricted by existing policy practices'. To ensure continual feedback and engagement with the university sector, Dawkins also appointed a group of vice-chancellors to provide feedback, which became known as the 'purple circle'.

In what turned out to be a crucial decision, in mid-1987, Dawkins also appointed Chapman to the team. Dawkins asked Chapman to prepare a report for inclusion in the green paper, outlining the costs and benefits of different user-pays higher education options. Chapman's paper included upfront fees with scholarships for the 'deserving poor' and governmentsubsidised bank loans, as well as the novel idea of an income-contingent charge to be repaid through the tax system following graduationsomething no other country had implemented. Because of the novelty of the policy, and the expected negative reaction from the ALP once fees 
were put on the table for serious discussion, Dawkins omitted Chapman's report from the green paper and instead established a committee to critically assess the options raised.

The committee was chaired by Neville Wran, an ALP icon and former premier of New South Wales. Also joining were Meredith Edwards, first assistant secretary from the Department of Social Security, and Bob Gregory, a professor of economics from The Australian National University with expertise in labour economics. Secretary of the committee was Mike Gallagher, first assistant secretary in the Department of Immigration, Local Government and Ethnic Affairs. Chapman served as a consultant and the committee was supported by an able secretariat, many of whose members were part of the green paper taskforce. The terms of reference for the Wran committee implicitly indicated the government's intention to reintroduce tuition fees.

\section{The Wran Report and the origin of HECS}

Prior to setting out options for financing, the Wran Report set out arguments for user pays, supported by data collected by Chapman and the committee secretariat. University students came predominantly from middle and upper-class families and, moreover, they benefited from attending university through higher employment rates and higher lifetime earnings. An inequity existed between those who participated and benefited and those who paid; the current system of no fees amounted to middle-class welfare. The argument for reintroduction of some level of fees was also strengthened by references to research that appeared to indicate little evidence of change in the socioeconomic mix of students following fee abolition in 1974 (Wran 1988). ${ }^{4}$

Options set out for raising contributions from individual beneficiaries included vouchers, fee schemes with and without exemptions, fee schemes with commercial or government-financed loans, graduate taxes and income-contingent debt arrangements. The Wran committee assessed these options on their impact on student demand and on equity by considering whether and how access and capacity to pay would be

4 Macintyre et al. (2013) note, however, that Don Anderson, the author of this early research, protested that his research findings were misrepresented. 
affected for students with different levels of disadvantage. Important also were the consequences to size and timing of revenue and administrative simplicity and costs.

The last two options considered were a graduate tax and ICLs, both of which involved repayments calculated as a proportion of taxable income. Arrangements by which graduates could use their human capital as equity to fund education were well known, having been first suggested by Friedman (1955)..$^{5}$ Unlike commercial or conventional loans, which would require repayment regardless of the capacity to repay, a graduate tax would eliminate repayment hardship and the risk of default. A graduate tax in its standard form, however, involves graduates repaying a proportion of their income for the duration of their working lives, with the consequence that the amount repaid would be unrelated to the fees charged. Furthermore, if only graduates were required to pay the tax, this could provide a disincentive to graduate. Chapman's paper also proposed a closely related option for an ICL, although in the report this was referred to as a tax debit scheme (Wran 1988). Unlike a graduate tax, the size of the liability would be fixed and directly linked to the costs of an individual's education and years of study. Repayments would therefore be not open-ended but limited to tuition fees. By linking repayments to a proportion of income, and by requiring repayment only once earnings reached a relatively high level, there would be low impact on equity and access. Furthermore, by requiring all students who incurred a debt to repay through an ICL, regardless of whether or not they graduated, all users would contribute.

Edwards et al. (2001) recall that discussions of the relative merits of the different options continued over several meetings. The compelling features of an ICL ultimately convinced the committee that this scheme was superior to the others considered:

[T] he user tax debt linked to cost of provision and the number of years of study is the only scheme that collects contributions from users and beneficiaries without compromising the Government's growth and equity objectives for higher education. (Wran 1988: 29)

5 Closely related ideas for funding higher education in Australia were put forward during the 1980 s by various economists. See Macintyre et al. (2017) for details of some of these proposals. 
The committee then turned to the task of setting scheme parameters that would be politically acceptable. A student contribution equal to 20 per cent of Commonwealth outlays on higher education was proposed-equivalent to $\$ 1,800$ per annum in 1988 prices for a fulltime student-as this was comparable both with average student charges prior to fee abolition in 1974 and with fees charged overseas at publicly funded higher education institutions (Wran 1988). Rather than a single fee level, however, the committee recommended three levels to reflect broad differences in the costs of course provision. Debtors should repay only if and when their income exceeded the annual average earnings of all employees, or $\$ 21,500$ in 1988 terms. Thus, most students would start repaying only once they entered the workforce, and the equity advantages were intentionally highlighted; those with little or no capacity to pay would not be required to do so, including those from disadvantaged backgrounds with low incomes and parents taking time off work for childrearing. For individuals whose income exceeded the threshold, the committee recommended a repayment rate of 2 per cent of income (Wran 1988).

After settling on the ICL as the preferred option, the problem remained that large initial outlays of public funds would be required, yet revenue from repayments would emerge only gradually over many years. This revenue lag could delay implementation of the reforms. A contentious issue was whether to raise revenue by requiring upfront contributions from students from wealthy families. The line of argument was that affluent families could afford tuition fees and so should be required to pay for their child to attend university. Another perspective-strongly advocated by Edwards et al. (2001) and supported by policy analysis - was that some students were unable to share in family income for a variety of reasons, so means-tested upfront contributions would harm access. Ultimately, rather than compulsory upfront payments, a decision was made to implement a 15 per cent loan discount to encourage upfront payments (Wran 1988; Edwards et al. 2001).

The core recommendation of the Wran committee was introduction of this new higher education contribution scheme, to be implemented from 1 January 1989 to new and existing students studying after that date. 
Administration would involve higher education institutions notifying DEET of each student's debt, which would in turn pass this information to the Australian Taxation Office (ATO). ${ }^{6}$

Release of the report was delayed to late April 1988, in part because acceptance of collection by the ATO was not initially forthcoming. Chapman was tasked with initial discussions with the ATO and recalls that, as an academic with little experience in policy implementation, he was naive about the expected response. At first, the ATO resisted collection, arguing that, on principle, it collected taxes and was not a debt collection agency, but its opposition waned on learning of Edwards's presence on the Wran committee. Edwards had been a ministerial consultant during development of the child support policy and the ATO had agreed to collect payments from noncustodial parents for child maintenance despite these payments not being a 'tax'. This precedent, as well as pressure from Keating (Chapman, personal correspondence), paved the way for the ATO to accept collection of HECS debts. The efficiencies of collecting through the ATO were also recognised. Edwards et al. (2001) and Chapman reflect that the initial caution by the ATO was rational and appropriate given its predominant role as a tax rather than a debt collection agency and the uncertainty regarding ATO resourcing needs once HECS was implemented.

Prior to release of the Wran Report, the name chosen for the loan scheme was the Australian Contribution to the Cost of Education Students Scheme (ACCESS). The provocative acronym faced criticism from higher education and student unions in a pre-release briefing (Chapman and Nicholls 2013), as well as from ALP elder Gough Whitlam (Macintyre et al. 2013). The name was soon changed to the Higher Education Contribution Scheme.

6 In addition to HECS, the committee made recommendations to abolish HEAC, increase income support coverage and rates, establish a tripartite body to develop arrangements for industry contributions and establish a trust fund to ensure HECS revenue was earmarked for improving student places and financial support (Wran 1988). 


\section{The path to legislation}

How HECS progressed so quickly from proposal to commitment to legislation is testament to the strength of the underlying economic arguments and the determination of Dawkins and his supporters.

Following the release of the Wran Report, the government was faced with the task of consulting with and convincing stakeholders and the public of the merits of the proposal. The report highlighted the selling points of HECS: 'free' higher education funding amounted to middle-class welfare and was regressive, so students should contribute to the costs of their education; and the scheme was fair because repayments would be required only from those with income above average taxpayer earnings. Dawkins and Walsh emphasised these points to gain political and public support for the scheme (Chapman and Hicks 2018).

Nevertheless, once the Wran Report was released, there were various levels of opposition from different quarters. This is no surprise. The ALP's platform at the time was opposed to fees, and the proposed ICL scheme had no international precedent-it was untested and there was no empirical evidence that it would succeed. Student rallies and demonstrations against HECS followed (Macintyre et al. 2013). The complexity and novelty of the policy led to difficulties in conveying the idea and to a misunderstanding among some opponents and the media. Many incorrectly referred to the scheme as a 'graduate tax' or simply as a 'tuition fee' (see, for example, Reid 1988). But when reliably worded polls were conducted, it was clear that a majority of the community was supportive of students paying at least part of the cost of their courses (Commonwealth of Australia 1988). Print media opinion pieces and editorials were also mostly supportive, acknowledging that deferred contingent repayments would not harm access (Chapman and Nicholls 2013).

Nevertheless, national student and staff unions lobbied the ALP Caucus, many members of which shared their strong views on keeping fees out of university (Macintyre et al. 2013). It was critical for Dawkins to secure support from the various Labor factions if there was to be hope for the policy. A cross-factional caucus consultative group was established to consider the Wran Report in May 1988, making recommendations to the Cabinet in July on the preferred scheme parameters, including the income threshold and repayment rates (Commonwealth of Australia 
1988). Importantly, Dawkins had the full confidence and support of Hawke and Keating (Dawkins 2018), and Keating helped to bring some of the factions into line.

The critical turning point came at the ALP National Conference in June 1988, with a close vote supporting a change to the policy platform of 'free tertiary education' to one that was instead free at the point of entry, thereby ensuring that qualified Australians would retain access to a tertiary education regardless of their means (Chapman and Nicholls 2013). This motion was seconded by the Australian Council of Trade Unions (ACTU) president Simon Crean. Bringing the ACTU on board was crucial for success. While the union's position prior to the national conference had been rejection of schemes requiring direct student or graduate contributions, blue-collar unions dominated the membership of the ACTU, and its members were paying taxes to fund the higher education costs of privileged students. The ACTU acknowledged that the Wran proposal was clearly preferable to other mechanisms for collection of student contributions (Commonwealth of Australia 1988). The heads of the universities were easier to persuade. The Australian Vice-Chancellors' Committee desired expansion of the sector but accepted that additional public funding might not be forthcoming and recognised that the Wran proposals were 'both feasible and the least inequitable of proposals for supplementary sources of funds' (Commonwealth of Australia 1988: 33).

When the Higher Education Funding Bill 1988 was introduced into parliament, Dawkins cautioned the opposition that HECS was 'a precondition for implementation of the other aspects of its higher education package' (Reid 1988). Nevertheless, the opposition ultimately voted against the Bill in the upper house. Dawkins recalls that the Bill drafted was 'basically Senate-proof'; it specified how much additional revenue each university would get if HECS was accepted, compared with a much lower amount if HECS was not passed (Dawkins 2018). Thanks in part to the wording of the Bill, and negotiation with the Australian Democrats, who had initially expressed strong opposition to HECS, the Higher Education Funding Bill was passed in December 1988, less than five months after the Cabinet's decision to adopt HECS as policy.

Once the dust settled, the scheme ultimately adopted looked very similar to that proposed by the Wran committee, but with a number of modifications: rather than three levels of charges, a flat contribution level of $\$ 1,800$ was chosen; the initial income threshold was increased slightly, 
to $\$ 22,000$; graduated rates of repayment of 1,2 and 3 per cent that varied by income were introduced; ${ }^{7}$ and students in certain courses (such as nursing) were exempted (Commonwealth of Australia 1988; Edwards et al. 2001).

\section{Delivery, legitimacy and endurance}

In the years following implementation, the success of HECS in facilitating expansion was apparent. Funded student places increased by 23 per cent between 1988 and 1993 (Williams 2013), which came on the back of growth in private student contributions. It was perhaps not surprising, then, that by 1993 the Liberal Party had changed its opinion, despite opposing the original reforms and in 1989 promising to abolish HECS if elected (Parliament of Australia 1989: 4361), to be replaced with upfront fees accompanied by fee-exempt scholarships. When John Hewson released the Liberal Party's 'Fightback!' economic policy package in the leadup to the 1993 election, this included a promise to keep HECS (Norton 2013). The Liberal Party had long been in favour of market-oriented fee flexibility and a voucher mechanism to distribute government subsidies and recognised that the income-contingent mechanism of HECS could be used to collect loan repayments. ${ }^{8}$

The legitimacy of HECS was reinforced in 1996 when the Coalition took power and the Howard Government chose its retention. They did, however, put their own mark on the policy, announcing the most wide-reaching changes to HECS since its introduction. That changes were announced in 1996 was not unexpected. In 1990, within one year of becoming legislation, repayment rates had risen by 1 percentage point and had then been increased by a further percentage point in 1994, despite the Wran committee recommending that a rate greater than 2 per cent would 'represent an unacceptably high annual additional tax impost' (Wran 1988: 58; Ey 2018). But, in 1996, the changes shifted

7 The Wran committee expressed concern that a threshold of $\$ 21,500$ would imply a high tax rate when individuals crossed the threshold, and instead recommended that DEET and the ATO develop phasing arrangements to reduce this effect (Wran 1988: 62). A feature of the Australian HECS system is that the repayment rates are applied to total income and not the marginal income that exceeds the income threshold. This has been subject to criticism (Highfield and Warren 2015) and differs from the repayment systems in the United Kingdom and New Zealand, which are based on marginal income. 8 See Norton (2013) for comprehensive coverage of Coalition education policies and reactions in the leadup to and following the Dawkins reforms. 
considerably more costs on to students. The most controversial change at the time was the lowering of the first repayment threshold to $\$ 20,701$. This was more than $\$ 10,000$ less than average earnings, ${ }^{9}$ breaking the link between repayment thresholds and average earnings that had been a key selling point of HECS.

The other notable changes were an almost doubling of average tuition charges per full-time year and introduction of differential HECS whereby three charge bands replaced the single flat rate. The bands broadly reflected the cost of course delivery, as was originally proposed in the Wran committee report and supported by the departments of Treasury and finance in 1988 (Commonwealth of Australia 1988); however, private returns also figured in the decision, with law courses placed in the highest charge band despite low costs of delivery (Higher Education Legislation Amendment Act 1996 [Cwlth]).

The increased HECS charges and reductions in repayment thresholds were introduced partly in response to a large budget deficit (Norton 2013). For better or worse, government funding was reduced and universities became more reliant directly on students for revenue. Between 1996 and 2001, the Commonwealth contribution to university income (excluding HECS) fell from 56.7 per cent to 43.8 per cent, while HECS income increased from 11.6 per cent to 17.4 per cent (Jackson 2003)..$^{10}$

The break in the link between the first repayment threshold and average earnings was partly restored in 2005 when the first threshold was increased. This was coupled with new repayment rates ranging from 4 per cent to 8 per cent. But the significant change in 2005 was to the organisational structure and funding arrangements. By 2005, the role of ICLs had expanded beyond HECS into a growing number of satellite programs, including the Postgraduate Education Loan Scheme, which provided HECS-style loans for full-fee postgraduate coursework students. In the interests of administrative and structural efficiency, an overarching umbrella scheme was introduced, the HELP (Ey 2018). HELP subsumed

9 Author's calculations.

10 It was also the case that universities became increasingly reliant on student fee income from international students during this period. 
HECS (thereafter known as HECS-HELP) and introduced FEE-HELP, which targeted full-fee-paying domestic students in nonsubsidised courses. ${ }^{11}$

Introduction of FEE-HELP was a particularly significant expansion of the original policy, because it extended HECS-style loans beyond the capped Commonwealth-subsidised places covered through HECS, including expansion into approved private institutions, and in so doing improved access to and diversity of opportunity for postgraduate students across the country: 'It gave students choices they would not otherwise have had between public and private education, between universities and smaller colleges, and between postgraduate courses in public universities' (Norton 2013: 297). Like HECS, FEE-HELP has endured since its inception.

The 2005 policy reforms also included significant changes to the funding arrangement between government and public universities. In 2005, a per-student funding model based on the concept of Commonwealthsupported places was introduced. Under this arrangement, the level of funding paid through the Commonwealth Grant Scheme to each higher education institution was calculated according to the number of Commonwealth-supported places and the corresponding funding rate for each place, which was set by the government and varied by field of study. This method of distributing government funding for higher education is still used today.

Significantly for HECS, universities were given permission to set their own student contribution levels — albeit up to a maximum set by the Commonwealth - and to retain the fees charged. Although the intention of this change was to promote competition in fees, in practice, universities raised their student contribution level to the maximum permittedapproximately 25 per cent above previous HECS charge amounts. As noted by Norton and Cherastidtham (2016), this was not surprising given demand for student places greatly exceeded supply. Moreover, as discussed in the final section of this chapter, because price sensitivity is low under an ICL, increasing fees would be expected to have very little effect on deterring enrolments.

11 FEE-HELP replaced the previous Open Learning Deferred Payment Scheme, the Postgraduate Education Loan Scheme and the Bridging for Overseas-Trained Professionals Loan Scheme. To mitigate the costs to taxpayers of unpaid debt and forgone interest, a 20 per cent loan fee was applied to FEEHELP loans. OS-HELP was also introduced for students studying overseas for short durations. 
In the almost 15 years since the 2005 reforms to HECS, changes have been relatively minor-testament to the efficiency and fairness of the original design. Some of the more notable changes have included the removal of discounts on upfront and voluntary repayments and introduction of arrangements to collect debt from borrowers who move overseas, in response to recognition of an oversight in the original design.

In contrast to the relatively incidental modifications to HECS parameters, changes to higher education funding in the past decade have been significant, with consequences to the growth of outstanding HECS debt. In 2012, the 'demand-driven' funding system was introduced and caps on the majority of Commonwealth-supported bachelor degree places at public universities were lifted (Norton and Cherastidtham 2016). This increased competition, but also the growth of student numbers, taxpayer outlays and the potential costs associated with HECS.

It was estimated that uncapping of places would add an additional $\$ 7.6$ billion to taxpayer costs over five years, and these rising costs were part of the reasoning behind a radical proposal for change to the sector announced in 2014 by then education minster Christopher Pyne. The major piece of the proposed reforms was fee deregulation, coupled with a 20 per cent reduction to the Commonwealth's contribution (Commonwealth of Australia 2014). The proposed reforms were motivated in part by the belief that the existing uniformity of tuition fees was a constraint on innovation and that providing universities with the freedom to set their own fees would foster competition and efficiency and drive improvements in the quality of courses and programs. The proposals were met with concerns that deregulation could lead to a doubling-or worse- of fees and debt (DEET 2015). The government was unable to make a convincing case that the proposed reforms would produce the desired improvements to the sector, and the proposals were abandoned.

The clearest warning about the potential risks of market-driven fees in the presence of ICLs emerged following introduction of VET FEE-HELP for students in higher-level VET courses in 2008 and the subsequent closure of this scheme in 2016. Discussion of these and other risks and challenges facing HECS, and the key lessons from this policy case, is given in the next section. 


\section{Current pressures and future challenges}

The demand-driven system and expansion of HECS have led to a significant rise in the stock of outstanding debt. As of June 2017, outstanding HELP debts totalled $\$ 55$ billion-the majority of which derives from HECS (DEET 2017). Approximately 30 per cent of this is expected to not be repaid, but long-run taxpayer costs are dependent on future graduate earnings and the government cost of borrowing, so are highly uncertain. These costs arise because some borrowers will not earn enough to repay their loans in full (outstanding debt is forgiven when the debtor dies) and because loans are indexed against inflation, which is lower than the yield on the government securities issued to finance the loans. The rising costs of HELP have led to policy proposals that would further shift costs from taxpayers to students or would better target existing subsidies to those most in need. Proposals have included reducing the income thresholds, applying a real interest rate on outstanding debt, charging loan surcharges to new HECS debtors, recovering outstanding debt from deceased estates and tying HECS repayment to family income rather than individual income (Norton and Cherastidtham 2014, 2016).

Perhaps the most contentious debate concerns the disparities in HECS charges between different fields of study, the size of HECS charges and, specifically, what the overall split between public and private funding should be, noting that HELP costs are just one component of public expenditure on higher education. Determining how the costs should be distributed is problematic, partly because of the difficulty in quantifying the size of public benefits and because the debate tends to be driven more by political and ideological differences than by economic analysis.

Despite the gradual shift to greater user pays over the past 30 years, participation rates have remained strong under HECS. Why? First, HELP removes financial barriers to entry and repayments are required only if income exceeds the minimum threshold. Second, the private returns to higher education over secondary and vocational education are considerable (e.g. Norton 2012; Daly et al. 2015). Third, because HECS repayments are a proportion of income, a higher debt means additional repayments 10-15 years from now-far in the future from the perspective of an 18-year-old student. 
For these reasons, price sensitivity is very low under HECS. While this can be seen as a positive because it encourages participation, it also means that education providers have strong economic incentives to charge high fees, potentially in excess of the costs of the provision of education. This is because education providers face no direct financial consequences if students do not repay; when a student takes out a HELP loan, the government pays the tuition fees directly to the education provider and the student then repays the loan to the government if they earn enough in the future.

HECS tuition fees are capped and regulated, so excessive fees are not present. However, when VET-FEE HELP was introduced, providers could set their own fees in many parts of the sector. Some education providers engaged in price gouging and predatory lending to secure enrolments with little care for students' suitability or the prospects of course completion. Completion rates were consequently very poor and the number of loans and estimates of unpaid HELP debt ballooned (DEET 2017: 43). This led to closure of the scheme and replacement with the VET Student Loans scheme in January 2017, which has much tighter lending restrictions and loan amounts.

To hold universities more accountable for the prices charged and the quality of education, some have proposed linking the provision of government subsidies to HELP debt recovery or requiring universities to take on some of the risk of nonrepayment (Ergas 2014; Leaver 2015). One risk of proposals in which behaviour, funding or price is linked to debt recovery is that universities may favour disciplines that yield greater financial returns at the expense of socially important, but traditionally lower-paying disciplines. How to ensure that universities have 'skin in the game' is an unresolved challenge for ICL systems and governmentsubsidised student loan schemes more broadly.

\section{Key lessons}

The successful development, implementation and endurance of HECS was thanks to the fortuitous combination of the right fiscal and political environment, a determined and decisive minister and a supportive Cabinet, a capable group of individuals to conceive and develop the policy, a compelling argument for change grounded in fairness and an efficient design with administratively simple collection. 
Perhaps most critically, the political will and authority for change were strong (Dawkins 2018). The development and introduction of HECS occurred in an environment in which there was a university funding crisis and a compelling argument for student contributions on the grounds of equity. Dawkins led from the front and, while he faced challenges convincing ALP factions of the need for and merits of HECS, he had the support of the Cabinet, including the prime minister and the treasurer.

The policy design process that led to HECS was set and controlled by Dawkins and occurred quickly, providing limited time or opportunity for opponents to disagree (Edwards et al. 2001). Critical was the choice of Wran committee members and secretariat staff and selection of Chapman as advisor. Dawkins handpicked committee members with diverse policy and economic experience and secretariat staff with knowledge of the higher education environment and with the skills to produce objective and rigorous analysis (Edwards et al. 2001). The strength of arguments and comprehensiveness of the analysis helped convince the ALP and key interest groups of the inequity of the existing system and the merits of the deferred loan scheme. The analysis also stymied the influence of critics, who struggled to come up with superior policy alternatives.

Framing and language were critical to selling the policy proposal. Bob Gregory (2009: 239), a member of the Wran committee, noted that the advocates of HECS never described it as 'a fee regime with an optional and innovative loan system attached'. Rather, it was first and foremost a loan scheme. Gregory (2009) also notes that because the number of policy parameters for HECS was relatively small, this enabled decisionmaking to proceed quickly and did not distract from the task of selling the policy idea. Furthermore, since HECS was introduced on a greenfield policy site, policy constraints and conflicts did not exist to divert the development process.

Administrative efficiency and simplicity were crucial to the success and endurance of HECS. The serendipitous precedent of the collection of childcare maintenance payments by the ATO ensured the feasibility of its collection of HECS repayments. Efficiency of collection has since become recognised as a fundamental requirement and benefit of ICL schemes (Chapman et al. 2014). 
While Australia's two main political parties have embraced HECS as an essential feature of higher education policy, the scheme has been subject to incremental change, often driven by the political attraction of budgetary savings. Both parties have been responsible for reductions in Commonwealth spending on higher education, pushing greater costs on to students through increases in tuition fees and modifications to repayment thresholds and rates. ${ }^{12}$ This is not surprising. Demanding a greater share of costs from 'privileged' students rather than all taxpayers attracts less political and public resistance. It is also the case that changes to HECS are often not based on economic theory or evidence-based analysis, but are driven by compromise to achieve specific political objectives.

A final lesson is that the endurance of HECS has been dependent on the regulatory environment in which it operates. As discussed above, the imbalance in the risk-sharing arrangements between educational institutions and government and the very low price sensitivity of students due in part to the design of HECS have meant that caps on tuition fees have been necessary to guard against price gouging and blowouts in public costs. But, while government regulation can prevent exploitation of the system, the current arrangements of uniform HECS charges and uneven risk-sharing arguably restrict the incentives and opportunities for the higher education sector to innovate and diversify in teaching and course offerings. Dawkins believes the 1987 reforms are now out of date and has called for increased competition and a gradual transition to fee flexibility, albeit subject to strict provisions and controls (Dodd 2016).

The legitimacy and endurance of HECS have been due in large part to the fairness of the policy. It is considered fair because students, who benefit directly, contribute to the costs of their education. It is also seen as fair because it enables access to those without upfront funds and the risk of financial hardship is mitigated because repayments are based on income. A challenge when designing future reform is to do so without jeopardising the continued role of HECS as an affordable and equitable means of funding higher education.

12 In August 2018, legislation was passed that will reduce the first threshold to $\$ 45,000$ (Higher Education Support Legislation Amendment (Student Loan Sustainability) Act 2018 [Cwlth]). 


\section{References}

Australian Bureau of Statistics (ABS) 2017. Education and Work, Australia. Cat. No. 6227.0. Canberra: ABS.

Chapman, B. 2018. 'HECS: A hybrid model for higher-education financing.' In M. Fabian and R. Breunig (eds), Hybrid Public Policy Innovations: Contemporary policy beyond ideology. London: Taylor \& Francis.

Chapman, B. and Hicks, T. 2018. 'The political economy of the Higher Education Contribution Scheme.' In B. Cantwell, H. Coates and R. King (eds), Handbook on the Politics of Higher Education. Cheltenham, UK: Edward Elgar.

Chapman, B. and Nicholls, J. 2013. 'HECS.' In G. Croucher, S. Marginson, A. Norton and J. Wells (eds), The Dawkins Revolution: 25 years on. Melbourne: Melbourne University Publishing.

Chapman, B., Higgins, T. and Stiglitz, J. 2014. Income Contingent Loans: Theory, practice and prospects. London: Palgrave Macmillan.

Chingos, M. and Dynarksi, S. 2018. 'An international final four: Which country handles student debt best?' The New York Times, 2 April.

Commonwealth of Australia 1988. Establishing a Higher Education Contribution Scheme. Cabinet Submission No. 5922, 4 August. Canberra: Commonwealth of Australia.

Commonwealth of Australia 2014. Budget 2014-15: Higher education. Canberra: Commonwealth of Australia.

Croucher, G., Marginson, S., Norton, A. and Wells, J. (eds) 2013. The Dawkins Revolution: 25 years on. Melbourne: Melbourne University Publishing.

Daly, A., Lewis, P., Corliss, M. and Heaslip, T. 2015. 'The private rate of return to a university degree in Australia.' Australian Journal of Education 59(1): 97-112. doi.org/10.1177/0004944114565117.

Dawkins, J. 1987a. Higher education: A policy discussion paper. Green Paper, December. Canberra: AGPS.

Dawkins, J. 1987b. The Challenge for Higher Education in Australia. Canberra: AGPS.

Dawkins, J. 2018. The 2018 Wilson Dialogue: Removing reform roadblocks. National Gallery of Australia, Canberra, 30 May. 
Department of Employment, Education and Training (DEET) 2015. Higher Education in Australia: A review of reviews from Dawkins to today. Canberra: Commonwealth of Australia.

Department of Employment, Education and Training (DEET) 2017. Department of Education and Training Annual Report 2016-17. Canberra: Commonwealth of Australia.

Dodd, T. 2016. 'John Dawkins says his university reforms are "completely out of date".' Australian Financial Review, 26 September.

Dodd, T. 2017. 'ANU economist Bruce Chapman honoured with the AFR Higher Education Lifetime Achievement Award.' Australian Financial Review, 30 August.

Edwards, M., with Howard, C. and Miller, R. 2001. Social Policy, Public Policy: From problem to practice. Sydney: Allen \& Unwin.

Ergas, H. 2014. 'Creating mayhem more fun, but revolting radicals miss serious issue.' The Australian, 19 May.

Ey, C. 2018. The Higher Education Loan Program (HELP) and related loans: A chronology. Research Paper Series 2017-18. Canberra: Parliamentary Library.

Friedman, M. 1955. Capitalism and Freedom. Chicago: University of Chicago Press.

Gregory, B. 2009. 'Musing and memories on the introduction of HECS and where to next on income contingent loans.' Australian Journal of Labour Economics 12(2): 237-43.

Highfield, R. and Warren, N. 2015. 'Does the Australian Higher Education Loan Program (HELP) undermine personal income tax integrity?' eJournal of Tax Research 13(1): 202-61.

Jackson, K. 2003. Higher education funding policy. Parliamentary Library E-Brief. Canberra: Parliamentary Library. Available from: www.aph.gov.au/ About_Parliament/Parliamentary_Departments/Parliamentary_Library/ Publications_Archive/archive/hefunding.

James, R., Karmel, T. and Bexley, E. 2013. 'Participation.' In G. Croucher, S. Marginson, A. Norton and J. Wells (eds), The Dawkins Revolution: 25 years on. Melbourne: Melbourne University Publishing.

Leaver, S. 2015. An incentive compatible model for higher education deregulation. Submission No. 35, The Principles of the Higher Education and Research Reform Bill 2014, and Related Matters. Canberra. 
Macintyre, S., Brett, A. and Croucher, G. 2017. No End of a Lesson: Australia's unified national system of higher education. Melbourne: Melbourne University Publishing.

Macintyre, S., Croucher, G., Davis, G. and Marginson, S. 2013. 'Making the unified national system.' In G. Croucher, S. Marginson, A. Norton and J. Wells (eds), The Dawkins Revolution: 25 years on. Melbourne: Melbourne University Publishing.

Norton, A. 2012. Graduate Winners: Assessing the public and private benefits of higher education. Melbourne: Grattan Institute.

Norton, A. 2013. 'The coalition.' In G. Croucher, S. Marginson, A. Norton and J. Wells (eds), The Dawkins Revolution: 25 years on. Melbourne: Melbourne University Publishing.

Norton, A. and Cherastidtham, I. 2014. Doubtful Debt: The rising cost of student loans. Melbourne: Grattan Institute.

Norton, A. and Cherastidtham, I. 2016. HELP for the Future. Melbourne: Grattan Institute.

Norton, A., Cherastidtham, I. and Mackey, W. 2018. Mapping Australian Higher Education 2018. Melbourne: Grattan Institute.

Organisation for Economic Co-operation and Development (OECD) 2017. Education at a Glance 2017: OECD indicators. Paris: OECD Publishing. doi.org/10.1787/eag-2017-en.

Parliament of Australia 1989. Senate, Debates, No. 138, 12 December, p. 4361. Canberra: Parliament of Australia.

Reid, R. 1988. 'Opposition stance the final hurdle for graduate tax.' Australian Financial Review, 8 November.

Universities Australia 2015. Higher Education and Research Facts and Figures. November. Canberra: Universities Australia.

Williams, R. 2013. 'System funding and institutional allocation.' In G. Croucher, S. Marginson, A. Norton and J. Wells (eds), The Dawkins Revolution: 25 years on. Melbourne: Melbourne University Publishing.

Wran, N. 1988. Report of the Committee on Higher Education Funding. 27 April. Canberra: AGPS. 
This text is taken from Successful Public Policy: Lessons from Australia and New Zealand, edited by Joannah Luetjens, Michael Mintrom and Paul 't Hart, published 2019 by ANU Press, The Australian National University, Canberra, Australia.

doi.org/10.22459/SPP.2019.03 